\title{
Effect of Nanofillers on Abrasion Resistance of Carbon Fiber Reinforced Phenolic Friction Composites
}

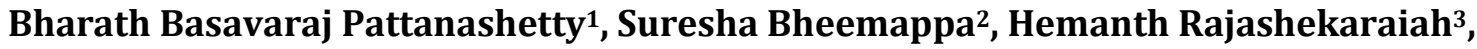 \\ Somashekar Hirehally Mahadevappa ${ }^{4}$ \\ ${ }^{1}$ Department of Automobile Engineering, Sri Jagadguru Mallikarjuna Murugharajendra Institute of Technology, \\ Chitradurga, India \\ ${ }^{2}$ Department of Mechanical Engineering, The National Institute of Engineering, Mysore, India \\ ${ }^{3}$ Department of Mechanical Engineering, NIE Institute of Technology, Mysore, India \\ ${ }^{4}$ Department of Mechanical Engineering, Dr. Ambedkar Institute of Technology, Bengaluru, India \\ Email: bharathauto999@gmail.com, sureshab@nie.ac.in, hemanth@nieit.ac.in,dr.hmsomashekar@gmail.com
}

How to cite this paper: Pattanashetty, B.B., Bheemappa, S., Rajashekaraiah, H. and Mahadevappa, S.H. (2019) Effect of Nanofillers on Abrasion Resistance of Carbon Fiber Reinforced Phenolic Friction Composites. Materials Sciences and Applications, 10, 65-77.

https://doi.org/10.4236/msa.2019.101007

Received: November 8, 2018

Accepted: January 13, 2019

Published: January 16, 2019

Copyright (c) 2019 by author(s) and Scientific Research Publishing Inc. This work is licensed under the Creative Commons Attribution International License (CC BY 4.0).

http://creativecommons.org/licenses/by/4.0/

\begin{abstract}
The present study focuses on the development of polymeric friction composites with short carbon fiber, micron and nano-sized fillers, additives with varying weight\% in phenol formaldehyde $(\mathrm{PF})$ matrix using hot compression moulding process. The composites prepared with fillers viz. Molybdenum disulfide or Molykote (MK) and multi walled carbon nanotubes (MWCNTs) in carbon fiber reinforced PF matrix is designated as Set-I composites. Inclusion of graphite and nano-clay in carbon fiber reinforced PF matrix is designated as Set-II composites. The prepared composites are tested in Dry sand rubber wheel abrasion wear test rig, following ASTM standards for evaluating the abrasive wear behaviour. From the routine experiments, it was observed that the presence of combined micro and nanofillers i.e. $11.5 \mathrm{wt} \% \mathrm{MK}+0.5 \mathrm{wt} \%$ MWCNTs of Set-I, has shown superior abrasion resistance among the study group. The test results of the Set-I and Set-II composites are analyzed using Taguchi experimental design followed by analysis of variance (ANOVA) to understand the contributions of wear control factors affecting the abrasive wear characteristics. Further, worn surface of selected samples is analyzed using scanning electron micrographs.
\end{abstract}

\section{Keywords}

Friction Composites, Nanofillers, Abrasion, Design of Experiments, Scanning Electron Microscope 


\section{Introduction}

Frictional materials used in automobile brake linings are multifarious composite materials, and they are well-known as: i) High-steel (semi-metallic) brake pads containing 30\% - 65\% metal, ii) Low-steel (low-metallic) brake pads containing $10 \%$ - 30\% metal, iii) Organic brake pads (also known as "non-asbestos organic" (NAO)) and iv) Hybrid brake pads, being a compromise between materials from group's ii and iii. High-steel and low-steel friction materials possess several disadvantages such as tendency to corrosion, low thermal stability, uneven wear of brake disk, etc., have restricted their braking applications. Modern friction materials familiarly known as non-asbestos organic (NAO) made of thermoset composites have been utilized extensively, starting from bicycles, light commercial vehicles, heavy vehicles, airplanes, etc. [1] [2] [3]. These friction materials are a mixture of several ingredients, which includes many fillers, lubricants, friction modifiers and reinforcing fibers bonded together by a thermosetting resin [4] [5] [6] [7]. Of several kinds of reinforcing fibers as support in polymer matrix composites, fibers made of glass, carbon, aramid and so on are broadly used. They are categorized by their aspect ratio. Polymers are further can be strengthened with different fillers that are accessible normally or synthesized in many forms such as, flakes, platelets, particles and so on to enhance their processability, mechanical, tribological and other performance, and in addition to reduce material cost. Filler particles of nano size with optimum loading percent have yielded the outstanding and synergistic performance in several characterization process. Many researchers have carried out the research on friction materials and the details of their research works has been discussed in Table 1.

Also, many investigations are made on tribological characterization aiming to evaluate fade and recovery behaviour of friction materials. However, abrasive wear from loose debris which is formed due to high pressure application need to be studied considering influential parameters like load, abrading distance and abrasive particle size. Hence, in view of cited literature above, the objective of the present work is to study the abrasive wear behaviour of phenolic friction materials. In particular, the three-body abrasive wear (3-BAW) behaviour of short carbon fiber reinforced phenolic friction composites with varying wt $\%$ of micro and nano-fillers, using Taguchi design of experiments and ANOVA to understand the control factors and their contributions affecting the wear characteristics.

\section{Experimental Details}

\subsection{Materials}

The source of the materials used to prepare the micro and nano fillers filled phenolic polymer composites in the present investigation are presented in Table 2.

\subsection{Fabrication Method}

The details of the fabrication method followed in the present work are discussed elsewhere [19]. The details of the hybrid composites prepared are listed in Table 3. 


\subsection{Three-Body Abrasive Wear Test}

The phenolic friction composite in automotive application as brake pads encounters the metallic surface of the drum during braking. This results in the generation of debris leading to the peel out of the fillers from the composite brake pads. These fillers act as the third body at the interface of the brake pad and the metallic drum surface. Hence the study of three-body abrasive (3-BAW) behaviour of phenolic friction composites is worth to discover. These tests were carried out using Magnum make Rubber wheel abrasion tester (RWAT) in accordance with ASTM G-65-16 [20]. Figure 1 shows the photograph of RWAT

Table 1. Literature review on polymeric friction materials.

\begin{tabular}{|c|c|c|}
\hline Reference & Research carried & Research outcome \\
\hline Blau [8] & $\begin{array}{l}\text { Reported on classification, typical properties and functions } \\
\text { of various binders, fillers additives along with reinforcing } \\
\text { fibers used in commercial brake materials formulation. }\end{array}$ & $\begin{array}{l}\text { Role of each constituent in friction and wear control, and effect } \\
\text { of their composition, form, distribution, and particle size was } \\
\text { briefly discussed. }\end{array}$ \\
\hline Bijwe et al. [9] & $\begin{array}{l}\text { Reviewed on friction materials for automotive braking } \\
\text { application, emphasizing development of semi metallic or } \\
\text { resin bonded metallic and various fibers reinforced } \\
\text { non-asbestos organics (NAO) braking materials. }\end{array}$ & $\begin{array}{l}\text { New classes of non-asbestos fiber reinforced organic polymeric } \\
\text { friction materials have completely replaced asbestos based } \\
\text { brake materials because of their superior performance and their } \\
\text { environmentally friendly nature. }\end{array}$ \\
\hline $\begin{array}{c}\text { Gurunath et al. } \\
{[10]}\end{array}$ & $\begin{array}{l}\text { Discussed about drawbacks of phenolic resin. In order to } \\
\text { overcome this, an alternative resin was synthesized and } \\
\text { tribo-tested to explore the possibility of replacing the } \\
\text { currently used phenolic. }\end{array}$ & $\begin{array}{l}\text { Composites prepared with new resin }(\mathrm{N}) \text { proved better than the } \\
\text { composite with traditional phenolic in all the } \\
\text { tribo-performance properties. }\end{array}$ \\
\hline Chan et al. [11] & $\begin{array}{l}\text { Reviewed the various materials and constituents used in } \\
\text { automotive brake friction material after the phasing-out of } \\
\text { asbestos. }\end{array}$ & $\begin{array}{l}\text { Mineral fillers (ceramic fillers) such as barite and clay are added } \\
\text { to increase the volume as well as to reduce the overall cost of a } \\
\text { composite on a volume basis. }\end{array}$ \\
\hline Kim et al. [12] & $\begin{array}{l}\text { The effects of reinforcing fibers on friction and wear } \\
\text { characteristics were investigated with an emphasis on the } \\
\text { friction film formation at the friction interface. }\end{array}$ & $\begin{array}{l}\text { The friction film with both aramid pulp and potassium titanate } \\
\text { maintained smooth friction surface and durable transfer film } \\
\text { resulted in improved wear resistance and steady friction force. }\end{array}$ \\
\hline Kato et al. [13] & $\begin{array}{l}\text { The importance of friction modifiers in friction materials, } \\
\text { such as abrasives and solid lubricants in achieving desired } \\
\text { range of friction was discussed. }\end{array}$ & $\begin{array}{l}\text { Functional fillers and inert fillers or space fillers can be used to } \\
\text { reduce the cost without affecting functionality of the friction } \\
\text { materials. }\end{array}$ \\
\hline $\begin{array}{l}\text { Tanaka et al. [14] } \\
\text { Moraw et al. [15] }\end{array}$ & $\begin{array}{l}\text { Proposed weight percentage of matrix, fiber and friction } \\
\text { modifiers for polymeric friction composites. }\end{array}$ & $\begin{array}{l}\text { Material comprising } 5 \mathrm{wt} \% \text { - } 20 \mathrm{wt} \% \text { binder resin, } 10 \mathrm{wt} \% \text { - } 50 \\
\mathrm{wt} \% \text { carbon or aromatic polyamide fiber, } 5-30 \mathrm{wt} \% \text { solid } \\
\text { lubricant and } 5 \mathrm{wt} \% \text { - } 20 \mathrm{wt} \% \text { ceramic powder exhibits stable } \\
\text { friction force and excellent wear resistance }\end{array}$ \\
\hline Ho et al. [16]. & $\begin{array}{l}\text { Investigated on the effect of different short fiber } \\
\text { reinforcement in friction materials. }\end{array}$ & $\begin{array}{l}\text { Short fibers reinforcement, is most often used to obtain synergistic } \\
\text { effect in mechanical and tribological performance of friction } \\
\text { materials. }\end{array}$ \\
\hline $\begin{array}{l}\text { Friedrich et al. } \\
\qquad[17]\end{array}$ & $\begin{array}{l}\text { Investigated the influence of particle size and filler contents } \\
\text { on the wear performance of nanoparticles reinforced } \\
\text { thermoplastics and thermosets. }\end{array}$ & $\begin{array}{l}\text { Presence of traditional fibers and/fillers with inorganic } \\
\text { nanoparticles yields an optimal effect and showed a clear } \\
\text { improvement in wear resistance of both thermosetting and } \\
\text { thermoplastic composites. }\end{array}$ \\
\hline Gopal et al. [18] & $\begin{array}{l}\text { Analyzed the synergistic effect of multi-ingredients on } \\
\text { friction and wear characteristics of friction materials. }\end{array}$ & $\begin{array}{l}\text { Suggests that, the combination of several ingredients (fibers, } \\
\text { micro/nano fillers and modifiers) and their synergism in a } \\
\text { commercial friction material makes it rather difficult to analyze } \\
\text { the friction and wear characteristics completely. }\end{array}$ \\
\hline
\end{tabular}


Table 2. Materials used in present investigation

\begin{tabular}{|c|c|c|c|c|c|}
\hline Sl. No. & Materials system & Designation & $\begin{array}{l}\text { Density } \\
\left(\mathrm{g} \mathrm{cm}^{-3}\right)\end{array}$ & Particle size & Suppliers \\
\hline & Binders & & & & \\
\hline 01 & Phenol formaldehyde & $\mathrm{PF}$ & 1.05 & $35 \mu \mathrm{m}$ & Claro India Pvt. Ltd, Chennai, India \\
\hline 02 & Cashew nut shell oil & CNSL & 0.95 & ------- & Sathya Cashew Chemical Ltd, Chennai, India \\
\hline 03 & Carbon powder & $\mathrm{CP}$ & 1.80 & $75 \mu \mathrm{m}$ & Mysore Pure Chemicals, Mysuru, India. \\
\hline \multirow[t]{2}{*}{04} & Plaster of Paris & POP & 2.07 & $30 \mu \mathrm{m}$ & Murugan Hardware, Erode, India \\
\hline & Fiber & & & & \\
\hline \multirow[t]{2}{*}{05} & Short carbon fiber & SCF & 1.60 & $\begin{array}{c}\Phi 10 \mu \mathrm{m} \\
\text { length } 6 \mathrm{~mm}\end{array}$ & Murugan Hardware, Erode, India \\
\hline & Fillers & & & & \\
\hline 06 & Cashew dust & $\mathrm{CD}$ & 0.65 & $15 \mu \mathrm{m}$ & Sathya Cashew Chemical Ltd, Chennai, India \\
\hline 07 & Copper powder & $\mathrm{Cu}$ & 8.92 & $25 \mu \mathrm{m}$ & Metal Powder Company India PVT Ltd, Sivakasi, India \\
\hline 08 & Silicon carbide & $\mathrm{SiC}$ & 3.20 & $25 \mu \mathrm{m}$ & Carborundum Universal Ltd (CUMI), Cochin, India \\
\hline 09 & Iron powder & FS & 7.20 & $20 \mu \mathrm{m}$ & Kumar Hardware, Coimbatore, India \\
\hline \multirow[t]{2}{*}{10} & Alumina & $\mathrm{Al} 2 \mathrm{O} 3$ & 3.95 & $20 \mu \mathrm{m}$ & Triveni Chemicals, Gujrat, India \\
\hline & Functional fillers & & & & \\
\hline 11 & Molybdenum disulfide or Molykote. & MK & 4.80 & $50 \mu \mathrm{m}$ & Mysore Pure Chemicals, Mysuru, India. \\
\hline 12 & Graphite & Gr & 2.26 & $50 \mu \mathrm{m}$ & Gowtham Chemicals, Chennai, India \\
\hline 13 & Multi walled carbon nano tube & MWCNT & 2.60 & $35-100 \mathrm{~nm}$ & 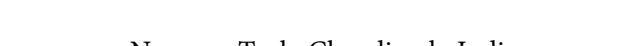 \\
\hline 14 & Nano clay & $\mathrm{NC}$ & 2.25 & $30-180 \mathrm{~nm}$ & Nanopar iecn, Cnandigam, mana \\
\hline
\end{tabular}

Table 3. Designations and constituents of thecomposites for Set-I and Set-II

\begin{tabular}{|c|c|c|c|c|c|}
\hline \multirow{3}{*}{$\begin{array}{l}\text { Designation } \\
\text { Sample Set-I }\end{array}$} & \multicolumn{5}{|c|}{ Composition } \\
\hline & \multirow{2}{*}{$\begin{array}{c}\text { Fibers (wt\%) } \\
\text { SCF }\end{array}$} & \multirow{2}{*}{$\begin{array}{c}\text { Binders (wt\%) } \\
\text { PF-17, CNSL-9.5, POP-1.5 and CP-2 }\end{array}$} & \multirow{2}{*}{$\begin{array}{c}\text { Fillers (wt\%) } \\
\text { Cu-8, FS-8, SiC-5, CD-7 and } \mathrm{Al}_{2} \mathrm{O}_{3}-5\end{array}$} & \multicolumn{2}{|c|}{ Functional fillers (wt\%) } \\
\hline & & & & MK & MWCNT \\
\hline S1C1CF & 25 & 30 & 33 & 12 & 0 \\
\hline $\mathrm{S} 1 \mathrm{C} 2 \mathrm{CF}$ & 25 & 30 & 33 & 11.75 & 0.25 \\
\hline S1C3CF & 25 & 30 & 33 & 11.5 & 0.5 \\
\hline Sample Set-II & SCF & PF-17, CNSL-9.5, POP-1.5 and CP-2 & $\mathrm{Cu}-8, \mathrm{FS}-8, \mathrm{SiC}-5, \mathrm{CD}-7$ and $\mathrm{Al}_{2} \mathrm{O}_{3}-5$ & Gr & NC \\
\hline $\mathrm{S} 2 \mathrm{C} 1 \mathrm{CF}$ & 25 & 30 & 33 & 12 & 0 \\
\hline $\mathrm{S} 2 \mathrm{C} 2 \mathrm{CF}$ & 25 & 30 & 33 & 11.75 & 0.25 \\
\hline S2C3CF & 25 & 30 & 33 & 11.50 & 0.5 \\
\hline
\end{tabular}

apparatus used for the 3-BAW tests. The size of the test samples are maintained to $75 \mathrm{~mm} \times 25 \mathrm{~mm}$. The test procedure followed in the present work is as discussed elsewhere [21] [22], further the specific wear rate $\left(\mathrm{K}_{\mathrm{s}}\right)$ are determined as mentioned in the reference [23]. The parameters for conducting the 3-BAW tests are listed in the Table 4. 


\subsection{Statistical Tool for Wear Characterization}

The 3-BAW routine experiments were conducted for the test parameters listed in the Table 4. However, the $K_{s}$ were found to be significant with applied normal load of $15 \mathrm{~N}$ and abrasive particle size of $300 \mu \mathrm{m}$. Hence they are considered as the constant factors in the present study. Further to understand the effect and contribution of abrading distance and filler content on $\mathrm{K}_{\mathrm{s}}$, they were considered for statistical analysis. Significant $\mathrm{K}_{\mathrm{s}}$ was found at the abrading distances of 280 , 570 and $1140 \mathrm{~m}$, hence abrading distance at these levels were considered for statistical analysis. The control factors and levels listed in Table 5, are used for statistical analysis of wear. An orthogonal array $(\mathrm{OA}) \mathrm{L}_{9}$ was chosen and the factors considered affecting the wear process are abrading distance (A) and filler

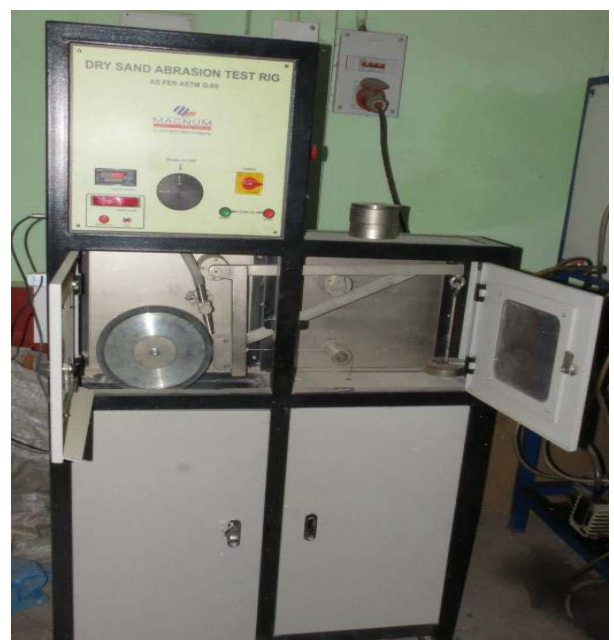

Figure 1. Dry sand rubber wheel abrasion test rig (RWAT).

Table 4. Test parameters considered for routine 3-BAW.

\begin{tabular}{cc}
\hline Test Parameter & \\
\hline Abrasive feed rate $(\mathrm{g} / \mathrm{min})$ & $255 \pm 5$ \\
Material of the wheel & Chlorobutyl rubber \\
Rubber wheel diameter $(\mathrm{mm})$ & 228 \\
Speed of rubber wheel $(\mathrm{rpm})$ & 200 \\
Abrading distance $(\mathrm{m})$ & $280,410,570,840$ and 1140 \\
Applied normal load $(\mathrm{N})$ & $5,7.5,10,12.5$ and 15 \\
Quartz abrasive particle size $(\mu \mathrm{m})$ & $150,210,300,354$ and 400
\end{tabular}

Table 5. Abrasive wear control factors and levels.

\begin{tabular}{cccc}
\hline & \multicolumn{3}{c}{ Levels } \\
\cline { 2 - 4 } Control factors & 1 & 2 & 3 \\
\hline Abrading Distance (A), (m) & 280 & 570 & 1140 \\
Nano Filler content (B), (wt\%) & 0.00 & 0.25 & 0.50 \\
\hline
\end{tabular}


content (B). The experimental data obtained are transformed into signal-to-noise $(\mathrm{SN})$ ratio by considering the minimization of $\mathrm{K}_{s}$. Analysis of variance (ANOVA) is used to reveal the level of significance of factors influencing wear. The percentage contribution by each of the process parameter in the total sum of the squared deviations can be used to evaluate the importance of the process parameter change on the performance characteristic. If the P-value (probability of significance) for a factor in the table is less than 0.05 (95\% confidence level) then it can be considered that, the effect of the factors is significant on the response.

\section{Results and Discussion}

\subsection{Three Body Abrasion Wear Study}

The abrasive wear behaviour of phenolic friction composites are determined on Rubber wheel abrasion tester (RWAT). Figure 2 demonstrates the 3D surface plot with filler content in $\mathrm{X}$-axis, abrading distance in $\mathrm{Y}$-axis and $\mathrm{K}_{\mathrm{s}}$ in $\mathrm{Z}$-axis, revealing the combined effect of filler content and abrading distance on wear behaviour of the phenolic friction composites.

The $\mathrm{K}_{\mathrm{s}}$ decreases with the increase in abrading distance and with the inclusion of MWCNT along with molykote (Set-I series) and nano clay along with graphite (Set-II series), maintaining almost the same trend with marginal difference in $\mathrm{K}_{\mathrm{s}}$. However, the $\mathrm{K}_{\mathrm{s}}$ of Set-I series is comparatively lesser than that of the Set-II series. The role of filler content can be observed in the plot, which results in the significant reduction of $\mathrm{K}_{\mathrm{s}}$. The $\mathrm{K}_{\mathrm{s}}$ was found to be high without the nano fillers and inclusion of the same upto $0.5 \mathrm{wt} \%$, has resulted in the decrease of $\mathrm{K}_{\mathrm{s}}$. However, routine experiments were conducted with the phenolic composites loaded with higher concentration of (i.e. $0.5 \mathrm{wt} \%$ to $1.0 \mathrm{wt} \%$ ) nano fillers. It was

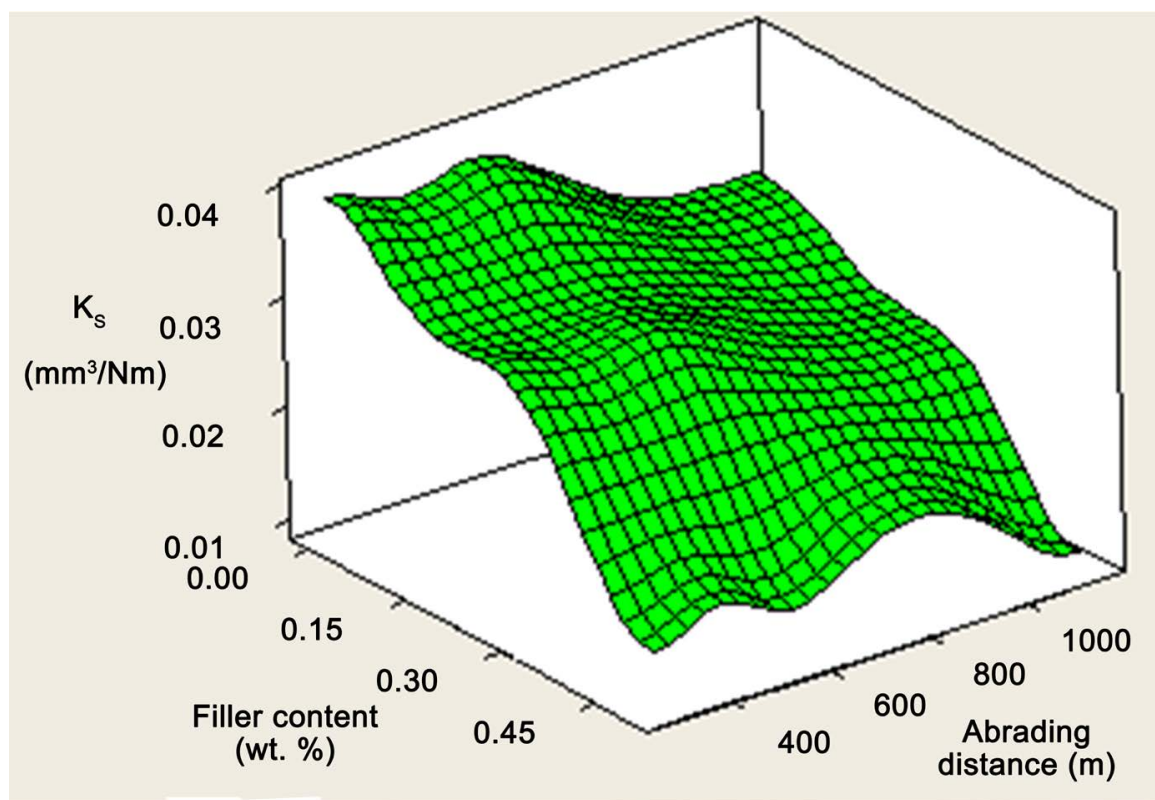

Figure 2. Surface plot revealing the combined effect of filler content and abrading distance on $\mathrm{K}_{\mathrm{s}}$ of Set-I composites. 
observed that the $\mathrm{K}_{\mathrm{s}}$ increased beyond $0.5 \mathrm{wt} \%$ loading of nano fillers. The similar findings were observed by other researchers [24] [25]. Hence in the present analysis, the composite with $0.5 \mathrm{wt} \%$ nano filler loading was considered.

\subsection{Worn Surface Morphology}

Figure 3 presents the SEM image of worn surface of polymeric friction composites (PFC) filled with $11.5 \mathrm{wt} \%$ of molykote $+0.5 \mathrm{wt} \%$ of MWCNT subjected to $15 \mathrm{~N}$ applied normal load, abraded to a distance $1140 \mathrm{~m}$ with abrasive particle size of $300 \mu \mathrm{m}$. This composite has demonstrated high resistance to abrasion wear in the study group. Very few filler pull-out (indicated as FP), fiber pull-out (indicated as SP) and fiber rupture (indicated as SR) can be seen in the Figure 3. This has resulted in low wear volume of the composite in the study group. Good bonding of matrix with the fiber is evident from the image resulting in improved abrasive wear resistance.

Figure 4 presents the SEM image of worn surface of PFC filled with $12 \mathrm{wt} \%$ graphite subjected to $15 \mathrm{~N}$ applied normal load, abraded to a distance $1140 \mathrm{~m}$

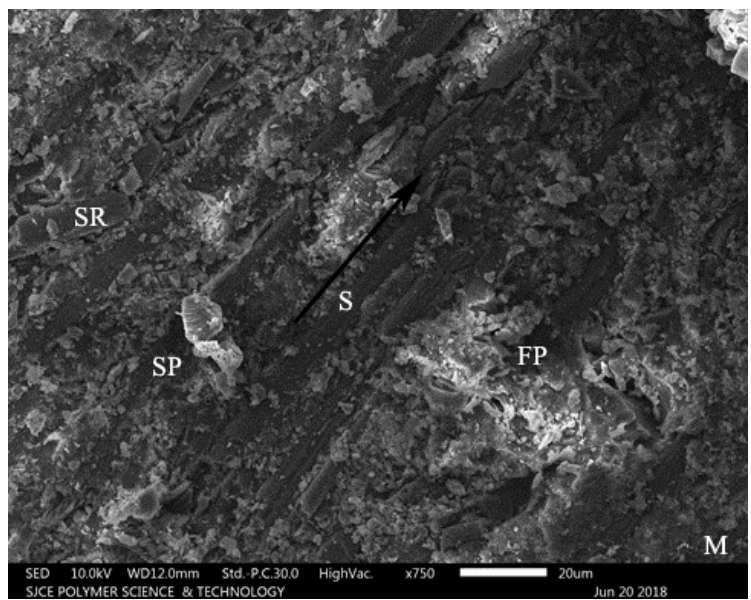

Figure 3. SEM image of worn surface of PFC filled with $11.5 \mathrm{wt} \%$ molykote $+0.5 \mathrm{wt} \%$ MWCNT.

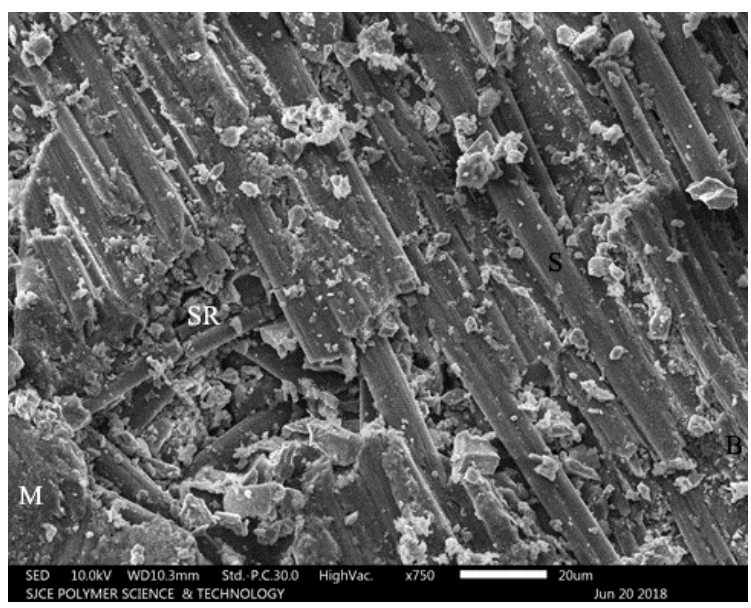

Figure 4. SEM image of worn surface of PFC filled with $12 \mathrm{wt} \%$ graphite. 
with abrasive particle size of $300 \mu \mathrm{m}$. Inclusion of graphite has deteriorated the hardness of the composite resulting in low resistance to the abrasion wear. The matrix material (indicated as $\mathrm{M}$ ) has been abraded and the short carbon fiber have been exposed to abrasive particles resulting in fiber rupture (indicated as SR), fiber pull-out and filler pull-out. This has resulted intense abrasion wear loss.

\subsection{Statistical Analysis of Three-Body Abrasive Wear Data}

Wear parameters that is abrading distance and filler content are considered as controlling factors at three different levels. Table 5 shows the control factors and their levels considered for the experimentation. The $\mathrm{L}_{9}$ orthogonal array $(\mathrm{OA})$ of experiments along with the experimental wear responses are shown in Table 6. The responses was analyzed to obtain signal to noise ratio, using the MINITAB 17 software, specifically used for the design of experiments (DOE) applications. The mean of signal to noise ratio was found to be $33.8783 \mathrm{~dB}$ for Set-I and $32.766 \mathrm{~dB}$ for Set-II composites respectively.

Figure 5 shows the graphs denoting the effect of the control factors on the $\mathrm{K}_{\mathrm{s}}$ of Set-I and Set-II composites respectively. Process parameter settings with the highest SN ratio always gave the optimum quality with minimum variance. The graphs show the change of the SN ratio when the setting of the control factor was changed from one level to the other. The best $\mathrm{K}_{\mathrm{s}}$ were at the higher $\mathrm{SN}$ ratio values in the response graphs. From the graph, it is clear that control factor combination of A3 and B3 gives minimum $K_{s}$. Thus, minimum $K_{s}$ for the developed composite materials are obtained when the abrading distance $(\mathrm{A})$ and filler content (B) are at the highest level. The SN ratio response of Set-I and Set-II composites is presented in Table 7. The SN ratio delta values of A and B for Set-I composites are 2.65 and 8.35: and for Set-II composites are 2.65 and 9.21 respectively. The strongest influence on the $\mathrm{K}_{\mathrm{s}}$ was shown by factor $\mathrm{B}$, followed by factor $\mathrm{A}$, in both material groups under study.

Table 6. OA of experiments, responses and corresponding SN ratios.

\begin{tabular}{|c|c|c|c|c|c|c|}
\hline \multirow{2}{*}{$\begin{array}{l}\text { Exp. } \\
\text { No. }\end{array}$} & \multirow{2}{*}{$\begin{array}{c}\text { Abrading } \\
\text { Distance (m) }\end{array}$} & \multirow{2}{*}{$\begin{array}{l}\text { Filler content } \\
\quad(w t \%)\end{array}$} & $\mathrm{K}_{\mathrm{s}}\left(\mathrm{mm}^{3} / \mathrm{Nm}\right)$ & SN Ratio (dB) & $\mathrm{K}_{\mathrm{s}}\left(\mathrm{mm}^{3} / \mathrm{Nm}\right)$ & SN Ratio (dB) \\
\hline & & & \multicolumn{2}{|c|}{ Set-I } & \multicolumn{2}{|c|}{ Set-II } \\
\hline 1 & 280 & 0.00 & 0.0347763 & 29.1743 & 0.039041 & 28.1696 \\
\hline 2 & 280 & 0.25 & 0.0247382 & 32.1326 & 0.031838 & 29.9411 \\
\hline 3 & 280 & 0.50 & 0.0133018 & 37.5218 & 0.013519 & 37.3810 \\
\hline 4 & 570 & 0.00 & 0.0341662 & 29.3281 & 0.038356 & 28.3234 \\
\hline 5 & 570 & 0.25 & 0.0243042 & 32.2864 & 0.031279 & 30.0948 \\
\hline 6 & 570 & 0.50 & 0.0130685 & 37.6755 & 0.013282 & 37.5347 \\
\hline 7 & 1140 & 0.00 & 0.0256247 & 31.8268 & 0.028767 & 30.8221 \\
\hline 8 & 1140 & 0.25 & 0.0182281 & 34.7852 & 0.023459 & 32.5936 \\
\hline 9 & 1140 & 0.50 & 0.0098014 & 40.1743 & 0.009962 & 40.0335 \\
\hline
\end{tabular}


(a)

Main Effects Plot for SN ratios

Data Means

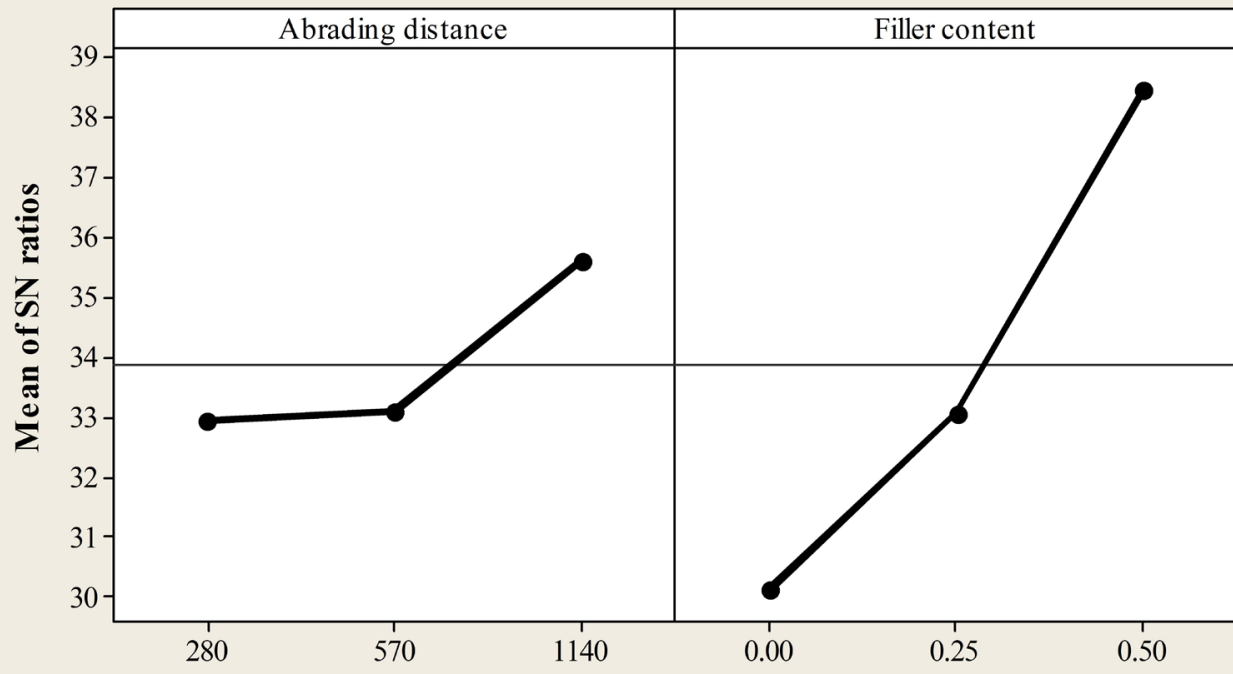

Signal-to-noise: Smaller is better

(b)

Main Effects Plot for SN ratios

Data Means

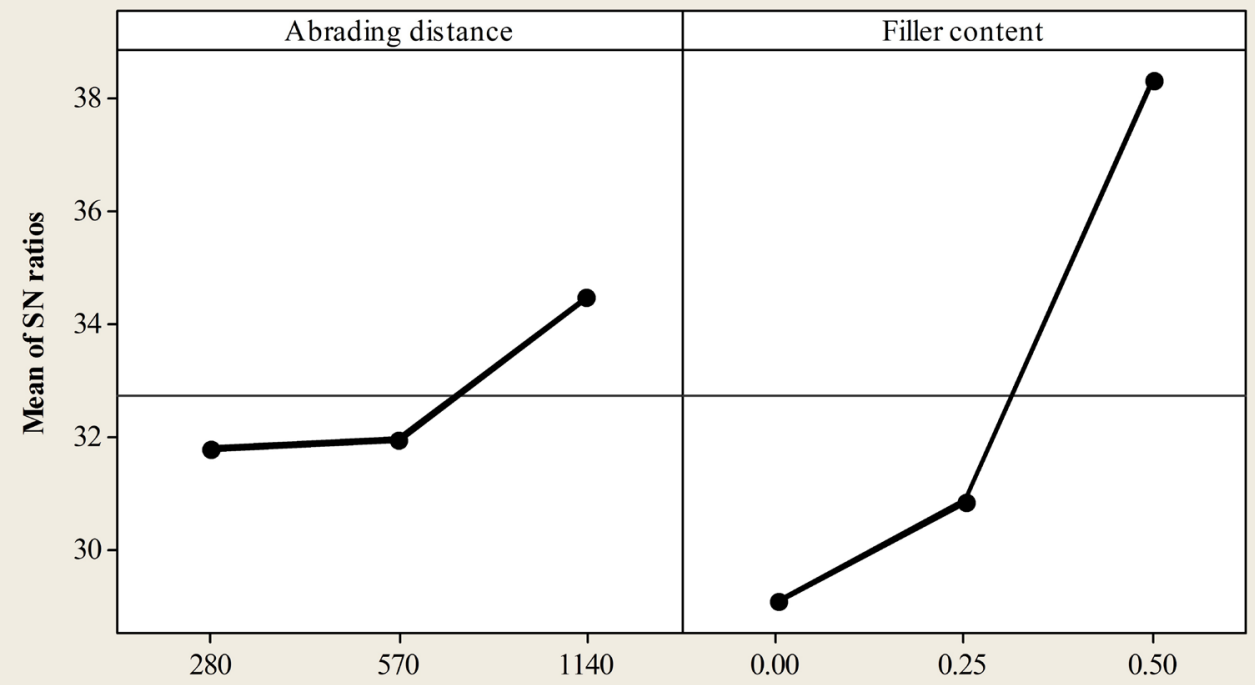

Signal-to-noise: Smaller is better

Figure 5. Plot demonstrating the main effects for SN ratio, (a) Set-I and (b) Set-II.

Table 7. Response table for SN ratio of Set-I and Set-II composites.

\begin{tabular}{lllll}
\hline Level & Abrading Distance & Filler content & $\begin{array}{l}\text { Abrading Distance } \\
\text { Set-II }\end{array}$ & Filler content \\
& Set-I & & 31.83 & \\
1 & 32.94 & 30.11 & 31.98 & 29.11 \\
2 & 33.10 & 33.07 & 34.48 & 30.88 \\
3 & 35.60 & 38.46 & 02.65 & 38.32 \\
Delta & 02.65 & 08.35 & 02 & 09.21 \\
Rank & 02 & 01 & & 01 \\
\hline
\end{tabular}




\subsection{Analysis of Variance and the Effects of Control Factors}

The ANOVA with $\mathrm{K}_{\mathrm{s}}$ results are listed in Table 8 for Set-I and Set-II composites respectively. This analysis was undertaken for a level of significance of $5 \%$, that is, for level of confidence $95 \%$. The last column of the table indicates the order of significance among control factors. It could be observed from Table 8 that the control factor B (P value $=0.000)$ has greater static influence of $86.806 \%$ and $\mathrm{A}$ $(\mathrm{P}$ value $=0.013)$ has an influence of $11.6687 \%$ on $\mathrm{K}_{\mathrm{s}}$ of the material system under study. Also for Set-II from Table 8 the control factor B $(\mathrm{P}$ value $=0.000)$ has greater static influence of $87.8719 \%$ and $A(P$ value $=0.016$ ) has an influence of $10.5838 \%$ on $\mathrm{K}_{\mathrm{s}}$ of the material system under study. The present analysis shows that 3-BAW test parameters that are, abrading distance and filler content have both statistical and physical significance.

\subsection{Confirmation Test}

The confirmation test is the final step in the DOE process. The purpose of the confirmation test is to validate the conclusions drawn during the analysis phase. The estimated SN ratio for $\mathrm{K}_{\mathrm{s}}$ using the optimum level of parameters are calculated as discussed elsewhere [26] [27].

The results of experimental confirmation were carried out by comparing the predicted $\mathrm{K}_{\mathrm{s}}$ with the actual $\mathrm{K}_{\mathrm{s}}$ using the optimal wear parameters are shown in Table 9. The change in the predicted to experimental results is about $1.41 \%$ (Set-I) and $1.19 \%$ (Set-II), which is well within the statistical confidence level. Therefore the $\mathrm{K}_{\mathrm{s}}$ of the friction composite material under study can be predicted with an allowable limit of $1.41 \%$ and $1.19 \%$ respectively.

Table 8. Analysis of Variance for $\mathrm{K}_{\mathrm{s}}$.

\begin{tabular}{|c|c|c|c|c|c|c|c|}
\hline \multicolumn{8}{|c|}{ Set-I Composites } \\
\hline Source & $\mathrm{DF}$ & Seq SS & Adj SS & Adj MS & $\mathrm{F}$ & Pvalue & $\mathrm{PC}(\%)$ \\
\hline Abrading distance (A) & 2 & 0.0000765 & 0.0000765 & 0.0000383 & 15.31 & 0.013 & 11.6687 \\
\hline Filler content (B) & 2 & 0.0005691 & 0.0005691 & 0.0002846 & 113.86 & 0.000 & 86.8060 \\
\hline Error & 4 & 0.0000100 & 0.0000100 & 0.0000025 & & & 01.5253 \\
\hline Total & 8 & 0.0006556 & & & & & 100.000 \\
\hline \multicolumn{8}{|c|}{$S=0.00158090,0 R-S q=98.48 \%, R-S q(\operatorname{adj})=96.95 \%$} \\
\hline \multicolumn{8}{|c|}{ Set-II Composites } \\
\hline Source & $\mathrm{DF}$ & Seq SS & Adj SS & Adj MS & $\mathrm{F}$ & Pvalue & $\mathrm{PC}(\%)$ \\
\hline Abrading distance (A) & 2 & 0.0001028 & 0.0001028 & 0.0000514 & 13.71 & 0.016 & 10.5838 \\
\hline Filler content (B) & 2 & 0.0008535 & 0.0008535 & 0.0004268 & 113.86 & 0.000 & 87.8719 \\
\hline Error & 4 & 0.0000150 & 0.0000150 & 0.0000037 & & & 01.5443 \\
\hline Total & 8 & 0.0009713 & & & & & 100.000 \\
\hline \multicolumn{8}{|c|}{$S=0.00193597 R-S q=98.46 \% R-S q(a d j)=96.91 \%$} \\
\hline
\end{tabular}

DF: Degree of Freedom, Seq SS: sequential sum of squares, Adj MS: adjusted mean squares, F: variance P value: test statistics, PC (\%): percentage of contribution. 
Table 9. Confirmation test for the tested friction composite.

\begin{tabular}{cccccccc}
\hline Set & $\begin{array}{c}\text { Abrading } \\
\text { distance }\end{array}$ & Filler content & $\begin{array}{c}\text { Predicted } \\
\mathrm{K}_{\mathrm{s}}\left(\mathrm{mm}^{3} / \mathrm{Nm}\right)\end{array}$ & $\begin{array}{c}\text { Predicted SN } \\
\text { ratio }\end{array}$ & $\begin{array}{c}\text { Experimental } \mathrm{K}_{\mathrm{s}} \\
\left(\mathrm{mm}^{3} / \mathrm{Nm}\right)\end{array}$ & Experimental SN ratio & $\begin{array}{c}\text { Percent } \\
\text { change }\end{array}$ \\
\hline I & 570 & 0.5 & 0.0141 & 37.0443 & 0.0139 & 37.6755 & 1.41 \\
II & 570 & 0.5 & 0.01346 & 37.9813 & 0.0133 & 37.5347 & 1.19 \\
\hline
\end{tabular}

\section{Conclusions}

- Inclusion of $11.5 \mathrm{wt} \%$ of MK and $0.5 \mathrm{wt} \%$ of MWCNT in PF composites exhibited highest abrasion resistance among the composites under study.

- Nano fillers had beneficial effect on the abrasion behaviour of PF composites under study.

- Filler concentration played a vital role with a contribution of around $87 \%$ in 3-BAW behaviour of the PF composites.

- It is observed that minute agglomerates facilitated in forming a network which helped in improving the abrasion wear resistance.

\section{Conflicts of Interest}

The authors declare no conflicts of interest regarding the publication of this paper.

\section{References}

[1] Nicholson, G. (1995) Facts about Friction: A Friction Material Manual Almost All You Need to Know about Manufacturing; 100 Years of Brake Linings \& Clutch Facings. P \& W Price Enterprises, Incorporated.

[2] Tsang, P.H.S., Jacko, M.G. and Rhee, S.K. (1985) Comparison of Chase and Inertial Brake Dynamometer Testing of Automotive Friction Materials. Wear, 103, 217-232. https://doi.org/10.1016/0043-1648(85)90012-2

[3] Berry, M. (1997) Mesothelioma Incidence and Community Asbestos Exposure. Environmental Research, 75, 34-40. https://doi.org/10.1006/enrs.1997.3770

[4] Luo, S., Liu, X., Mu, S., Tsai, S.P. and Wen, C.P. (2003) Asbestos Related Diseases from Environmental Exposure to Crocidolite in Da-Yao, China. I. Review of Exposure and Epidemiological Data. Occupational and Environmental Medicine, 60, 35-42. https://doi.org/10.1136/oem.60.1.35

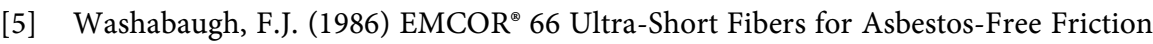
Materials. SAE Transactions, 928-935. https://doi.org/10.1136/oem.60.1.35

[6] Kumar, M. and Bijwe, J. (2010) Role of Different Metallic Fillers in Non-Asbestos Organic (NAO) Friction Composites for Controlling Sensitivity of Coefficient of Friction to Load and Speed. Tribology International, 43, 965-974. https://doi.org/10.1016/j.triboint.2009.12.062

[7] Stachowiak, G. and Batchelor, A.W. (2013) Engineering Tribology. ButterworthHeinemann.

[8] Blau, P.J. (2001) Compositions, Functions, and Testing of Friction Brake Materials and Their Additives (No. ORNL/TM-2001/64). Oak Ridge National Lab., TN (US). https://doi.org/10.2172/788356

[9] Bijwe, J. (1997) Composites as Friction Materials: Recent Developments in Non- 
Asbestos Fiber Reinforced Friction Materials-A Review. Polymer Composites, 18, 378-396. https://doi.org/10.1002/pc.10289

[10] Gurunath, P.V. and Bijwe, J. (2007) Friction and Wear Studies on Brake-Pad Materials Based on Newly Developed Resin. Wear, 263, 1212-1219.

https://doi.org/10.1016/j.wear.2006.12.050

[11] Chan, D.S.E.A. and Stachowiak, G.W. (2004) Review of Automotive Brake Friction Materials. Proceedings of the Institution of Mechanical Engineers, Part D: Journal of Automobile Engineering, 218, 953-966. https://doi.org/10.1243/0954407041856773

[12] Kim, S.J., Cho, M.H., Lim, D.S. and Jang, H. (2001) Synergistic Effects of Aramid Pulp and Potassium Titanate Whiskers in the Automotive Friction Material. Wear, 251, 1484-1491. https://doi.org/10.1016/S0043-1648(01)00802-X

[13] Kato, T. and Magario, A. (1994) The Wear of Aramid Fiber Reinforced Brake Pads: The Role of Aramid Fibers. Tribology Transactions, 37, 559-565. https://doi.org/10.1080/10402009408983329

[14] Tanaka, T., Tamura, H., Sawano, K. and Hiramatsu, N. (1996) US Patent No. 5516587. US Patent and Trademark Office, Washington DC

[15] Moraw, K. and Paul, H.G. (1983) US Patent No. 4373038. US Patent and Trademark Office, Washington DC.

[16] Ho, S.C., Lin, J.C. and Ju, C.P. (2005) Effect of Fiber Addition on Mechanical and Tribological Properties of a Copper/Phenolic-Based Friction Material. Wear, 258, 861-869. https://doi.org/10.1016/j.wear.2004.09.050

[17] Friedrich, K., Zhang, Z. and Schlarb, A.K. (2005) Effects of Various Fillers on the Sliding Wear of Polymer Composites. Composites Science and Technology, 65, 2329-2343. https://doi.org/10.1016/j.compscitech.2005.05.028

[18] Gopal, P., Dharani, L.R. and Blum, F.D. (1994) Fade and Wear Characteristics of a Glass-Fiber-Reinforced Phenolic Friction Material. Wear, 174, 119-127. https://doi.org/10.1016/0043-1648(94)90093-0

[19] Bharath, P.B., Suresha, B. and Hemanth, R. (2017) Effect of Filler-Filler Interactions on Mechanical Properties of Phenol Formaldehyde Based Hybrid Composites. International Journal of Engineering and Technologies, 13, 24-38.

[20] ASTM G65-16 (2016) Standard Test Method for Measuring Abrasion Using the Dry Sand/Rubber Wheel Apparatus.

[21] Harsha, A.P., Tewari, U.S. and Venkatraman, B. (2003) Three-Body Abrasive Wear Behaviour of Polyaryletherketone Composites. Wear, 254, 680-692. https://doi.org/10.1016/S0043-1648(03)00142-X

[22] Suresha, B. and Chandramohan, G. (2008) Three-Body Abrasive Wear Behaviour of Particulate-Filled Glass-Vinyl Ester Composites. Journal of Materials Processing Technology, 200, 306-311. https://doi.org/10.1016/j.jmatprotec.2007.09.035

[23] Suresha, B., Chandramohan, G., Sampathkumaran, P. and Seetharamu, S. (2007) Three-Body Abrasive Wear Behaviour of Carbon and Glass Fiber Reinforced Epoxy Composites. Materials Science and Engineering: A, 443, 285-291. https://doi.org/10.1016/j.msea.2006.09.016

[24] Cho, M.H. and Bahadur, S. (2005) Study of the Tribological Synergistic Effects in Nano CuO-Filled and Fiber-Reinforced Polyphenylene Sulfide Composites. Wear, 258, 835-845. https://doi.org/10.1016/j.wear.2004.09.055

[25] Sun, L.H., Yang, Z.G. and Li, X.H. (2008) Mechanical and Tribological Properties of Polyoxymethylene Modified with Nanoparticles and Solid Lubricants. Polymer En- 
gineering Sciences, 48, 1824-1832. https://doi.org/10.1002/pen.21150

[26] Rajashekaraiah, H., Mohan, S., Pallathadka, P.K. and Bhimappa, S. (2014) Dynamic Mechanical Analysis and Three-Body Abrasive Wear Behaviour of Thermoplastic Copolyester Elastomer Composites. Advances in Tribology, 2014, Article ID: 210187. https://doi.org/10.1155/2014/210187

[27] Sudheer, M., Prabhu, R., Raju, K. and Bhat, T. (2012) Optimization of Dry Sliding Wear Performance of Ceramic Whisker Filled Epoxy Composites Using Taguchi Approach. Advances in Tribology, 2012, Article ID: 431903.

https://doi.org/10.1155/2012/431903 